\section{Marine Levels in South Italy}

AFTER a personal discussion with Mr. A. E. Gunther, I am writing with his encouragement to comment on his communication in Nature ${ }^{1}$ and with reference also to an earlier article in the Illustrated London News.

In those publications Mr. Gunther suggested that the supposed presence of Lithodomus borings in the columns of the temples at Prestum, and the presence of marine erosion terraces at a similar height of about $20 \mathrm{~m}$ in various parts of Italy and Sicily, combine to indicate an extensive rise and fall of relative sea-level in the whole of this area between about A.D. 500 and A.D. 1500 .

I feel that it is necessary to comment on this hypothosis since the literature shows that geologists and archæologists tend to accept uncritically publications on this topic, where they would be far more cautious in the mainstream of their respective disciplines. In the past this has resulted in misleading papers having a long-standing effect on the literature.

'This is not the place to produce a massive list of authorities, but I wish simply to outline a point of view which can be checked by referenco to recent authors on Pleisto. cene sea-levels, and regional archæology.

First, thoro has been no eustatic change of sea-level greater than $2 \mathrm{~m}$ in the past 2,000 years, and probably none more than $1 \mathrm{~m}$. During the past million years there have been froquent large oscillations of sea-level due to glacial control, resulting in the sea passing through the present level many times. There are thus many Pleistocene erosion traces within $20 \mathrm{~m}$ of present sea-level, but all older than 2,000 years.

Owing to tho seismicity of the west Italian coast it is possible for local earth movements, such as those which have occurred in the north Bay of Naples, to lower and raise archæological remains in such a way that erosion marks on the buildings are aligned with nearby Pleistocene traces of much greater age.

Many of the terraces at or near $20 \mathrm{~m}$ in south Italy are of such a nature as to have required hundreds, if not thousands, of years of erosion, while a postulated $20 \mathrm{~m}$ sea-levol between A.D. 500 and A.D. 1500 can only have remained at its maximum altitude for one century at the outside. If such a widespread submersion and uplift had occurred, 53 major coastal cities would have been inundated at a rate of $5-6 \mathrm{~m}$ per century, including Pisa, Civitavechia, much of Rome, Naples, Messina and Syra. cuse, as well as about $2,300 \mathrm{~km}^{2}$ of land. Apart from minor references to the spread of malarial swamps, which can result from silting with no change of level, there is no literary evidenco to support such an event, nor does archæological evidence support it.

Most of the sites in the area have been thoroughly excavated and there are no signs of general submersion, apart from a few scattered sites partly submerged to-day as a result of local earth movements. At Civitavechia, Rome, Naples, Salerno and Syracuse, there were buildings erected during the medieval period at water-level or within a few metres of it, and there is no evidence that marine sediments overlie these sites. Furthermore, the rapid accumulation of sediments at the mouths of many small rivers on the west coast of Italy implies a more or less constant relative sea-level, while if there had been a change much of this sediment would have been deposited farther inland and over archæological remains.

Department of Geography.

N. C. Flemming

University of Cambridge.

${ }^{1}$ Gunther, A. E., Nature, 201, 909 (1964).

A. E. Gunther describes rolatively large movements of uplift and subsidence of the land with respect to the sea in historical times in southern Italy. The Lithodomus borings at Paestum indicate a relative subsidence of the land, followed by an uplift of $18.5 \mathrm{~m}$, in the time that has elapsed since the construction of the temples. If Gunther's contention that the uplift has occurred since the Middle Ages is correct, then an average rate of uplift of approximately $3-4 \mathrm{~cm}$ per annum is implied. In Calabria, however, where a number of colleagues and $I$ have recently completed a geological survey of the whole province, at a scale of 1 : 25,000, for the Cassa per il Mezzogiorno, uplift has occurred at an appreciably slower rate.

A magnificent series of erosional levels occur round the coasts of Calabria, the highest reaching a height of $1,000 \mathrm{~m}$ above present sea-level. There is good evidence that the uplift movements, which raised the erosional surfaces to their present position, began during the Calabrian Stage of the Pleistocene, and, therefore, there has been approximately 1,000 $\mathrm{m}$ of uplift during the Quaternary. Assuming a duration of $10^{6}$ years for the Quaternary, the average rate of uplift during this time was approximately $1 \mathrm{~mm}$ per annum.

Variations in the rate of movement can be demonstrated by considering the ages of the various levels. The lowest, extending to a height of $120 \mathrm{~m}$ above soa-level, is of Tyrrhenian age, as shown by the Strombus bubonius fauna present in the vicinity of Reggio di Calabria. The next higher terrace has been attributed to the Sicilian, and the level above that, with a lower limit of about $300 \mathrm{~m}$, is probably of Calabrian age. The higher terraces, with the probable exception of the highest, $1,000 \mathrm{~m}$ level, can also be attributed to the Calabrian. It appears, therefore, that more than half the Quaternary uplift occurred during the Calabrian Stage, and that in post-Calabrian times the movement slowed down. Assuming the duration of the Calabrian was $3.5 \times 10^{5}$ years, then the average rate of uplift during that time was approximately $2 \mathrm{~mm}$ per annum. Again, assuming an age of $4 \times 10^{6}$ years for the Tyrrhenian terrace, the average rate of uplift since that time has been about $0.3 \mathrm{~mm}$ per annum.

The variations discussed here are all relatively long-term. Geological evidence for shorter-term variations is lacking. Coming to modern times, Omori ${ }^{1}$ has estimated that the average rate of uplift for the Calabro-Sicilian area, for for the period 1900-08, was $2-4 \mathrm{~mm}$ per annum. This figure is of the same order as those deduced above from the total Quaternary, the Calabrian and the post-Tyrrhenian uplifts, and leads one to assume that the rate of uplift in Calabria has been fairly constant throughout the Quater. nary up to the present day. This rate of movement is significantly less than that quoted above for Paestum. The probable reason for this difference is that Paestum is located in a particularly active geological zone.

During the survey of Calabria no evidence for a modern reversal of the uplift movement was observed. The Holocene sediments of the coastal plain, extending into the river valleys, indicate that there has been a relative subsidence of the land since the end of the last glaciation. but this was probably caused by the return of glacial melt water to the oceans. In all probability the uplift movement continued during the Holocene, but the rise in sea-level was greater than the uplift of the land and therefore a relative subsidence resulted. The most recent evidence, provided by remnants of modern raisod beaches, indicates that uplift is again dominant.

Two conclusions can be drawn from the foregoing discus sion. First, modern movements of uplift and subsidence in southern Italy have not been uniform over the whole region and therefore correlation of levels based on height above sea-level cannot be relied on except over relatively short distances. Secondly, the hypothesis of a widespread 18-m historical level carnot be sustained. Hunting Technical Services, Ltd.,
Boreham Wood, A. N. Burton Herts.

${ }^{1}$ Omori, F., Bull. Imp. Earthquake Comm., Tokyo, 5 (1913). 